\title{
Coordination between Urban Planning and Transportation: Regulatory and Operational Aspects
}

\author{
Anissa Benaiche $^{1}$
}

\begin{abstract}
The coordination between urban planning and transportation constitutes the keystone of a sustainable urban development. This coherence is a priority in planning documents but seems today difficult to implement. In this framework, the aim of this paper is to evaluate projects coordinating urban planning and transportation upon three sites of Pays de la Loire region (West France): Nantes-saint Nazaire metropolis, Angers and Le Mans. The comparison between these three cases of study is justifiable in regulatory and operational levels and requires the reading of planning documents (mainly the SCOT) and the interviews with actors for exposing operational implementation difficulties of different projects.
\end{abstract}

Keywords — urban planning, transportation, planning documents, actors, operational implementation.

\section{INTRODUCTION}

$\mathrm{U}$ NDERSTANDING the challenges of the coordination between planning policies and transportation policies is an active subject in France for many years. The commitment to articulate urban planning and transportation is imposed recently [1] and this link is emphasised after the Urban Renewal and Solidarity Law (SRU 2000) [2]. This law tends toward a more coherent urban planning by establishing the Territorial Cohesion Scheme (SCOT), which has replaced the Development and Town Planning Master Plan (SDAU). The SCOT contributes to develop urban governance [3] and it is implemented by regional authorities, public administrative area groupings (EPCI) and public interest groupings.

The coordination of urban planning with transportation is one of priority levers in SCOT to work towards a sustainable mobility [4], to find a solution to urban sprawl [5] and to promote a sustainable urban development. However, in practice, this coordination today seems difficult to implement $[6,7]$. Consequently, we search to know how do communities integrate this coordination in SCOT? and how is this coordination translated concretely on the ground?

We assume that the standards of mobility and urban planning are clearly listed in SCOT and the link between these two components cannot be designed and conducted in the same manner [8]. This articulation meets with specific constraints to communities and lands. To test this hypothesis, we try to evaluate the various projects coordinating urban

\footnotetext{
${ }^{1}$ Laboratoire ESpaces et Sociétés (ESO). Institut de Géographie et d'Aménagement Régional de l'Université de Nantes (IGARUN), France.
}

planning and transportation across SCOT scale in order to know the empirical elaborations, to judge actions, to highlight compliance or not between forecasts and actual measures implemented and to take into account the operational implementation constraints. With these aims in mind, this paper is organized in two parts. The first specifies how the coordination between urban planning and transportation is presented in SCOT, the second focuses on the actions taken and the different constraints.

Otherwise, this evaluative study requires two main tools for its realization: documentary reading of SCOT and semistructured interviews with urban planners and mobility experts. The study concerns also three sites (covered by SCOT) of Pays de la Loire region: Nantes-Saint Nazaire metropolis, Angers and Le Mans (table I). The metropolitan SCOT Nantes-Saint Nazaire concerns a wider territory than the two others and covers a larger number of people.

These three cases of study are comparable because the three SCOT were approved at different times. This shows that under normal conditions, some projects take an operational progress compared to others. The comparison is also justifiable because each SCOT hinges on specific orientations to articulate urban planning and transportation. The following section describes these guidelines. 
TABLE I: GENERAL CHARACTERISTICS OF SCOT (SOURCE: DREAL DES PAYS DE LA LOIRE, LE SUIVI DES SCOT, 2014)

\begin{tabular}{|c|c|c|c|c|c|c|}
\hline SCOT & Progress state & Dates & Communities & $\begin{array}{l}\text { Number of } \\
\text { communes }\end{array}$ & $\begin{array}{c}\text { Population } \\
(2011)\end{array}$ & $\begin{array}{c}\text { Surface area } \\
\left(\mathrm{km}^{2}\right)\end{array}$ \\
\hline \multirow{6}{*}{$\begin{array}{l}\text { Metropolitan } \\
\text { SCOT Nantes- } \\
\text { Saint Nazaire }\end{array}$} & \multirow{6}{*}{$\begin{array}{l}\text { In revision: } \\
\text { taken } \\
\text { deliberation } \\
\text { (approved in } \\
2007 \text { ) }\end{array}$} & \multirow{6}{*}{$22 / 03 / 2013$} & $\begin{array}{l}\text { CU* Nantes } \\
\text { Métropole }\end{array}$ & 24 & \multirow{6}{*}{817774} & \multirow{6}{*}{1659} \\
\hline & & & $\begin{array}{l}\text { CA** Région } \\
\text { Nazarienne et de } \\
\text { l'Estuaire }\end{array}$ & 10 & & \\
\hline & & & $\begin{array}{l}\text { CC ***Région de } \\
\text { Blain }\end{array}$ & 4 & & \\
\hline & & & CC Erdre et Gevres & 12 & & \\
\hline & & & CC Loire et Sillon & 8 & & \\
\hline & & & CC Coeur d'Estuaire & 3 & & \\
\hline \multirow{4}{*}{ Angers SCOT } & \multirow{4}{*}{$\begin{array}{l}\text { Prescribed } \\
\text { (approved in } \\
\text { 2011) }\end{array}$} & \multirow{4}{*}{$17 / 11 / 2014$} & $\begin{array}{l}\text { CA Angers Loire } \\
\text { Métropole }\end{array}$ & 33 & \multirow{4}{*}{313389} & \multirow{4}{*}{1000} \\
\hline & & & $\begin{array}{l}\text { CC Vallée Loire } \\
\text { Authion }\end{array}$ & 8 & & \\
\hline & & & CC Loir & 13 & & \\
\hline & & & CC Loire Aubance & 14 & & \\
\hline \multirow{6}{*}{ Le Mans SCOT } & \multirow{6}{*}{ Approved } & \multirow{6}{*}{$29 / 01 / 2014$} & $\begin{array}{l}\text { CU Le Mans } \\
\text { Métropole }\end{array}$ & 14 & \multirow{6}{*}{260279} & \multirow{6}{*}{800} \\
\hline & & & CC Portes du Maine & 10 & & \\
\hline & & & $\begin{array}{l}\text { CC Sud Est du Pays } \\
\text { Manceau }\end{array}$ & 5 & & \\
\hline & & & $\begin{array}{l}\text { CC Orée de Bercé- } \\
\text { Bélinois }\end{array}$ & 8 & & \\
\hline & & & CC Bocage Cénoman & 5 & & \\
\hline & & & CC Rives de Sarthe & 4 & & \\
\hline
\end{tabular}

*Urban community

*** Conurbation community

****Commune communities

\section{RELATION BETWEEN URBAN PLANNING AND TRANSPORTATION IN SCOT: DESCRIPTIVE APPROACH}

The trend towards urban sprawl [9] and the increase of automobile travel brought the different actors through the three SCOT to change mobility behavior by rethinking the overall urban structure. Since the planning intention accompanies the search of new urban models [8], the actors have opted for the multipolar organization that differentiates the municipalities served by transport infrastructure in several scales (metropolitan, local, etc.).

Each designated polarity must respect specific rules of space consumption. In accordance with category, some municipalities can develop and can be served by public transport; the others will not be urbanized. Nevertheless, the success of the multipolar organization is only observable in the long term, at that time, we will check whether this organization would have been the best solution in a context where the car is king, or it would be necessary to opt instead for another spatial organization more centered on transport infrastructure, such as transport corridors by intensifying urbanization on travel axes.

In another vein, each SCOT leans on specific orientations to articulate urban planning and transportation. Thus, the SCOT of Le Mans recommends the multifunctional reuse of abandoned railways and the concentration of urbanization around the main rail stations to reinforce their vocation to become hubs for the region. The SCOT of Angers advocates the easy permeability of urban fabric to the passage of public transport through the urbanization of new areas. Moreover, it requires the intensification of urbanization in served sites and corridors of public transport structuring lines. As for the metropolitan SCOT Nantes-Saint Nazaire, its level of recommendation is not clearly because it advises in general the preservation of rail lines, the concentration of urbanization around structuring centers and the contribution to link urban planning with transportation. That being said, the next section shows the consideration of SCOT instructions across the three sites.

\section{URBAN PLANNING AND TRANSPORTATION BETWEEN ACTIONS AND COERCIONS}

\section{A. Focus upon Projects}

Discussions with actors have helped to highlight the progress of different projects coordinating urban planning and transportation. Table II illustrates a general view on the evaluation of the most significant actions since the approval of SCOT. In regard to comparison, the differences are evident in the progress of projects in connexion with territory and local contexts. Indeed, all projects articulating urban planning and transportation cannot be funded at the same time, they usually require for their completion a funding involving a prioritization process. Overall, this evaluative study shows that the metropolitan area of Nantes-Saint Nazaire seems to take the lead by engaging several actions aimed to limit the car use (carpool areas, ticketing, reopening of the tram-train line Nantes-Châteaubriant in 2014, etc.). The same observation is noted for Le Mans territory with the creation of two suburban express lines in 2017.

From another angle, some identified actions are common between the three grounds. We mention firstly the development/expansion of public transport to consolidate 
urban projects and strengthen the urban areas servicing. This shows that the policy of actors tends to promote the reconstruction of the city on itself near the public transport by filling the hollow teeth and avoid an expensive extension of transport infrastructure to the low density suburban fabric. We quote secondly the concrete advancement of rail policy in the region through actions such as the development of railway stations, the deploying of light displays, etc. We quote lastly the will to articulate urban planning and rail transport through several projects which have in common the railway station (existing or created) as a catalyst for urban development and an alternative to the car. Thus, the project of railway station can be designed to boost the served area (e.g. Moncé-en-Belin in Le Mans SCOT); can accompany a project of the concerted development zone (e.g. Trélazé in Angers SCOT) or can serve a major urban project (e.g. Savenay in the metropolitan SCOT Nantes-Saint Nazaire).

\section{B. Coercions of Operational Implementation Projects}

Despite the tangible progress of certain projects articulating urban planning and transportation, the actors explain that the concrete translation of standards enrolled in SCOT may be difficult. Several constraints brake the operational implementation of projects. It is commonly accepted that the main difficulty is closely related to projects context which is characterized by a rapid motorization, a lack of land and a low financial capacities. The financial aspect $[3,10]$ is responsible for the progressive implementation of projects on short, medium and long term. It is very delicate since on the one hand, the creation of equipments, services, etc. and the development of the areas around stations require a precise financial analysis by the community. On the other, the financing of different actions related to mobility and urban planning requires a real scaling work. The rarefaction of public funds is another point for discussion. Indeed, the priority of the authorities is to make an effective and less expensive urban development.

TABLE II: A GLOBAL EVALUATION OF DIFFERENT ACTIONS (SOURCES: INTERVIEWS WITH ACTORS AND REPORTS OF RAIL LINES COMMITTEES)

\begin{tabular}{|c|c|c|c|c|c|}
\hline \multirow{2}{*}{ SCOT } & \multirow{2}{*}{ Actions } & \multicolumn{4}{|c|}{ Global evaluation } \\
\hline & & Realized & In progress & Predicted & Completions \\
\hline \multirow{10}{*}{ 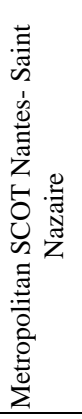 } & Urban programming and management of stationing around stations & Yes & Yes & / & l \\
\hline & $\begin{array}{c}\text { Commercial proposition of Liber'tan ticketing for retaining } \\
\text { occasional customers }\end{array}$ & Yes & / & / & l \\
\hline & Study of the reorganization of the central station of Nantes & / & Yes & / & / \\
\hline & Planning of the access to Rezé-Pont-Rousseau station & Yes & / & I & / \\
\hline & $\begin{array}{c}\text { Programming of light displays in Bouaye, Thouaré-sur-Loire and } \\
\text { Mauves-sur-Loire stations }\end{array}$ & Yes & Yes & l & l \\
\hline & Accessibility of persons with reduced mobility to stations & Yes & / & l & / \\
\hline & Restoration of Nort-sur-Erdre station & Yes & / & / & / \\
\hline & Prioritization of roads and speeds healing & / & Yes & I & / \\
\hline & Promoting of carpool areas & Yes & / & / & / \\
\hline & Planning of transportation at metropolitan scale & Yes & l & I & l \\
\hline \multirow{10}{*}{ 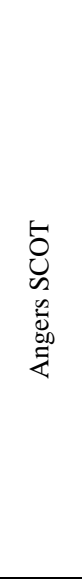 } & Creation of Trelazé station (budget of 5,3 millions€) & & Yes & & 2017-2018 \\
\hline & $\begin{array}{c}\text { Planning of the access to La Ménitré and Saint-Mathurin-sur-Loire } \\
\text { stations }\end{array}$ & Yes & l & l & l \\
\hline & Planning of Le Vieux Briollay station (15260€) & Yes & / & / & / \\
\hline & Restoration of La Ménitré station & Yes & / & l & / \\
\hline & $\begin{array}{c}\text { Installation of Cyclo-block in stations (Angers-Maitre-Ecole, Le } \\
\text { Vieux Briollay, La Ménitré, Saint-Mathurin-sur-Loire and } \\
\text { Savennières-Béhuard) }\end{array}$ & Yes & l & l & / \\
\hline & $\begin{array}{c}\text { Programming of light displays in La Ménitré, Saint-Mathurin-sur- } \\
\text { Loire, Le Vieux Briollay and La Bohalle stations }\end{array}$ & / & Yes & l & l \\
\hline & Accessibility of persons with reduced mobility to stations & Yes & l & l & l \\
\hline & $\begin{array}{l}\text { Urban renewal and concentration of housing and activities near } \\
\text { public transport }\end{array}$ & Yes & / & l & / \\
\hline & Study on the tram line & / & l & Yes & 2020 \\
\hline & $\begin{array}{c}\text { Expansion of transport networks (tram or bus) to consolidate } \\
\text { projects (Ponts-de-Cé, Saint Sylvain/Chene vert, Avrillé/ } \\
\text { Beaucouzé) }\end{array}$ & / & l & Yes & $\begin{array}{l}\text { In the long } \\
\text { term }\end{array}$ \\
\hline \multirow{8}{*}{ 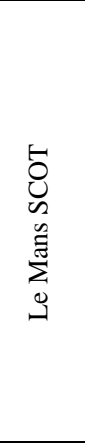 } & $\begin{array}{c}\text { Creation of car parks near Montbizot, Teillé, La Guièrche, Neuville- } \\
\text { sur-Sarthe and Laigné-Saint-Gervais stations }\end{array}$ & Yes & Yes & l & l \\
\hline & Restoration of Arnage and Laigné-Saint-Gervais stations & Yes & Yes & / & / \\
\hline & $\begin{array}{l}\text { Installation of Cyclo-block in stations (Teillé, Arnage, Champagné, } \\
\text { Ecommoy, Montbizot, La Guièrche and Laigné-Saint-Gervais) }\end{array}$ & Yes & / & l & l \\
\hline & Programming of light displays in Champagné station & & Yes & l & / \\
\hline & Accessibility of persons with reduced mobility to stations & Yes & Yes & / & / \\
\hline & $\begin{array}{l}\text { Creation of Moncé-en-Belin (3,8 millions } €) \text { and Le Mans Hopital } \\
\qquad(5,5 \text { millions } €) \text { stations }\end{array}$ & / & / & Yes & Post 2017 \\
\hline & Creation of two suburban express lines & / & / & Yes & $\begin{array}{l}\text { From now to } \\
2017\end{array}$ \\
\hline & $\begin{array}{l}\text { Creation of the tram line and a high quality service bus (action } \\
\text { accompanied by urban concentration) }\end{array}$ & / & Yes & l & l \\
\hline
\end{tabular}


Other factors impact the progress of projects. So technically, the project of a new transport infrastructure to serve an existing or planned neighbourhood can be challenging for the following reasons: the project itself has become too expensive or insufficiently structuring or it is less interesting because of low commercial potential. This is why in most of the time; a political demand to study an alternative is required.

Politically and institutionally, the differentiation of institutional scales and visions/goals is another coercion proved in several researches [3, 8, 10, 11, and 12]. Concerning institutional scales, we have a system of territories in which several skills are juxtaposed and superimposed. The juxtaposition results from the existence of administrative boundaries (department, region...) while the superimposition is related to the fact that networks are managed by different transport authorities [11]. This superposition operates a share of transportation competence and therefore an institutional entanglement which may cause the complication of decisions and the difficult sharing of transportation management. That's why, proceed to cooperate transport authorities with affected communities is a condition to articulate urban planning and transportation.

In this framework related to competencies, the recent law on the new territorial organization of the French Republic adopted on March $10^{\text {th }}, 2015$ by the national assembly, could have an impact in the future on the actors' skills starting with the new role assigned to regions. Indeed, they will manage in 2017 the departmental and school transport; this new responsibility will reduce the competences of departments. That being said, this reduction of competences will facilitate things or it will cause troubles regarding the coordination between urban planning and transportation? However, the departments will have to provide financial support to municipalities and public administrative area groupings within their projects.

Morphologically, the difficulties are mainly related to land and urban form. The use of hollow teeth is a real tool for urban concentration, but this operation is somewhat subtle. The government, through various tax incentives, encourages owners to sell these plots, but the problem lies in the fact that these building plots are sometimes farmland. The considerable increase in the property tax on building land doesn't allow farmers to pay this tax, so, they are forced to sell them. The judgment of the agricultural development of these areas can in some cases promote urban sprawl. Moreover, the filling of hollow teeth can be linked to other constraints such as the issue of connecting to other neighbourhoods, the development of roads and pedestrian traffic, etc.

In addition to land constraints, urban form is another point discussed with actors and that affects several aspects. The first concerns the supply and the demand for housing. In Angers, for example, some neighbourhoods stem from intensification operations and well served by public transport do not fulfill, there are especially many investors and students. The offer is higher than the demand generating repercussions on the use of public transport. This leads us to question the intensity of density chosen initially by the designers of different urban forms. Putting precisely the density threshold while adapting to different contexts allows a better articulation between urban planning and transportation.

The second aspect relates to the urban form itself. In front of more theoretical discourses of experts and the gap between different expectations, choosing an urban form efficient in space is needed to respond effectively to citizens' expectations and accommodate both promoters' expectations and preliminary objectives. On the other hand, this choice is difficult within a context from a very spread urban heritage. Urban sprawl thus constitutes the third aspect. Such is the case of Le Mans where urban sprawl was done naturally because of the car and houses. The link between urban planning and transportation is very diffuse and the real difficulty lies in the fact to better coordinate housing and public transport.

Ultimately, other hydraulic and environmental constraints (flooding, presence of noise, wetlands, etc.) can compromise the projects. In Moncé-en-Belin for example, the presence of wetland in the central area will curb its future urbanization, especially since it concerns projects of the tunnel and postage of the railway.

\section{CONCLUSION}

This evaluative study done after the approbation of SCOT reveals that the development of a territory and the operational implementation of different actions coordinating urban planning and transportation do not operate quickly. The time factor is crucial to lead to a successful coordination of policies which have a spatial impact in major urban areas [5]. It is still crucial for the advancement of local practices and the fulfilment of a mutual influence between transportation and cities in a complex and dynamic system. Considering the very long term $[12,13]$, this co-dependency is necessary to achieve a more sustainable future [6].

This study also reveals the gap which could be among the recommendations and the actual measures implemented. This difference is explained by the existence of operational difficulties and leads to question about how to proceed on the terrain. This questioning can be treated differently in accordance with the actors' visions by giving relevant proposals and opening the debate on the future. Thus, the improvement of decision making conditions, the knowledge of links between transportation policies and urban policies [14] can contribute to better coordination between urban planning and transportation.

Through the experience presented in this paper, two major challenges may be prescribed in the context of a sustainable development policy. The first is to promote the sustainable city by reducing urban sprawl, by counteracting the tendency to palliative and by cogitating strategically about land settlement. The second consists to organise and make denser spaces around stations and public transport lines. This density is not the only solution; the implementation of bikeways schemes by communities is a good initiative too.

\section{ACKNOWLEDGMENT}

I want to thank the actors who have helped me to do this study: Katia Papillon (urban planning department of Monceen-Belin), Matthieu Georget (mixed syndicate of Pays du Mans), Lise Viossat (direction of urban planning and spatial 
development, Angers Loire Metropole), Olivier Sorin (direction of transportation and mobility, Angers Loire Metropole), Pierre Yves Laire (mixed syndicate of Pays Loire Angers), Jean Michel Reumeau (urban planning agency of Angers), Stephane Rondeau (urban planning agency of Angers), Laurie Mai Denoux (metropolitan pole of NantesSaint Nazaire) and Virginie Sancelme (metropolitan pole of Nantes-Saint Nazaire).

\section{REFERENCES}

[1] A. Hecker, "Mobilite en site propre et forme urbaine: une possible interaction?," Revue geographique de l'Est, 52(1-2), 2012.

[2] A. Hasan, "La coherence urbanisme transport: introuvable? Analyse comparative des politiques locales des quatre principales agglomerations de la region Champagne Ardenne," in les mobilites spatiales dans les villes intermediaires: territories, pratiques, regulations, M. Giroud, H. Mainet-Valleix and J. Edouard, Ed. Clermont-Ferrand: Presses universitaires Blaise Pascal, 2011, pp. 468483.

[3] C. Gallez, H. Maaksim, "A quoi sert la planification urbaine?," Flux, (3), pp. 49-62, 2007.

[4] V. Kaufmann and C. Jemelin, "Articulation entre urbanisme et transports: quelles marges de manoeuvre?," Revue internationale des sciences socials, (2), pp. 329-340, 2003.

[5] F. Sager, "Institutions metropolitaines et coordination des politiques publiques: une aqqc des arrangements politico-administratifs d'articulation entre urbanisme et transports en Europe," Revue internationale de politique comparee, 11(1), pp. 67-84, 2004.

[6] R. Cervero, "Integration of urban transport and urban planning," in the challenge of urban government: Policies and practices, M. Freire and R. Stren, Ed. Washington, D.C, the world Bank Institute, 2001, pp. 407427.

[7] H. Nessi and A. Delpirou, "Les politiques de developpement urbain durable face aux heritages territoriaux. Regards romains sur la coordination transport/urbanisme," Flux, (1), pp. 69-79, 2009.

[8] M.C. Fourny, G. Feyt, T. Leysens, S. Duvillard, K. Koop and M. Talandier, "Quelle gouvernance territorial pour une urbanisation orientee par le rail dans les aires metropolitaines? Les lecons d'une experimentation regionale," presented at the ASRDLF conference cultures, patrimoine et savoirs, Universite catholique de Louvain, 2013.

[9] B. Gosjean, Urbanisation sans urbanisme. Une histoire de la ville diffuse, Belgique Mardaga, 2010.

[10] V. Kaufmann, D. Joye, F. Sager and Y. Ferrari, Coordonner transports et urbanisme. Lausanne: Presses polytechniques et universitaires romandes, 2003.

[11] J-J. Bavoux, F. Beaucire, L. Chapelon and P. Zembri, Geographie des transports, Paris Armand Colin, 2005.

[12] G. Wulfhorst, A. L'Hostis and B. Puccio, "Urbanisme et transport dans les regions urbaines: enjeux et perspectives d'un urbanisme oriente vers le rail," Recherche-transports-securite, (94), pp. 11-26, 2007. http://dx.doi.org/10.3166/rts.94.11-26

[13] P. Vrain, "Ville durable et transports: automobile, environnement et comportements individuels," Innovations, (2), pp. 91-112, 2003. http://dx.doi.org/10.3917/inno.018.0091

[14] C. Grillet Aubert and S, Guth, Transport et architecture du territoire, recherche etat des lieux et perspectives, Paris Editions Recherches IPRAUS, 2003. 